\title{
Phantasia, Phainomenon and Dogma in Epictetus ${ }^{1}$
}

\author{
By Aldo Dinucci*
}

This paper aims at evaluating the relation between the concepts of phantasia, phainomenon and dogma in Epictetus' thought. To do that, we will divide our work in four main parts. In the first, we will present the fundamentals of the Stoic concept of phantasia and its related notions. In the second part, we will review and study the main translations of Encheiridion 1.5, trying to understand the meaning of phainomenon, where it is linked with the concept of phantasia. In the third part, we will study Epictetus' views about phantasia and its related concepts. In the fourth part, we will survey the occurrences of the words dogma and hypolepsis in Epictetus. At the conclusion of this paper, we will present a detailed account of the connection among the concepts of phantasia, phainomenon and dogma in Epictetus' Stoicism.

\section{Introduction}

This paper aims at evaluating the relation between the concepts of phantasia, phainomenon and dogma in Epictetus' thought. In order to do that, we will divide our work in four main parts. In the first one, we will present the fundamentals of the Stoic concept of phantasia and its associated notions, such as lekton and axioma.

In the second, we will review the main translations of Encheiridion $1.5^{2}$. This line is particularly important for our subject, since it establishes a relation between two of the three concepts in question: phantasia and phainomenon. After reviewing the most important translations, we will focus on Hadot's commentaries on that line. His commentaries are particularly important because he conceived, in two different works, two distinct possibilities of rendering phainomenon in this line.

* Doctor in Philosophy \& Associate Professor, Federal University of Sergipe, Brazil.

1. This paper is a revised version of the paper "Phantasia, phainomenon and dogma in Epictetus" presented at the Research Seminar in Classical Studies of the University of Kent (UK) in February of 2015. Our thanks to Renato Silva (UNIRIO-Rio de Janeiro), Leonidas Konstantakos (International University of Miami), Karla Pollmann (University of Kent), Kelli Rudolph (University of Kent), Luis Márcio Fontes (McGill Unversity) and Marcos Balieiro (Universidade Federal de Sergipe/Brazil) for their comments on an earlier draft

2. Abbreviations: AM: Against the professors (Sextus Empiricus) - D: Discourses (Epictetus) - DL: Life of eminent philosophers (Diogenes Laertius) - E: Encheiridion (Epictetus) - HP: Outlines of pyrrhonism - LS: The Hellenistic philosophers (Long \& Sedley). 
In the third part, we will assess Epictetus' views about phantasia and its related concepts, focusing on the relation between phantasia and the rational capacity (dynamis logike).

In the fourth part, we will survey the occurrences of the words dogma and hypolepsis. We will show that these words are synonymous and key concepts to understand the test of phantasiai in Epictetus.

At the conclusion of this paper, we will offer a comprehensive view about the interconnection of the concepts of phantasia, phainomenon and dogma in Epictetus' Stoicism, coming back to Hadot's different interpretations of E 1.5 and trying to decide which one is correct.

\section{Phantasia (Fundamentals)}

There is no consensus concerning the translation of the Greek term $\varphi \alpha \nu \tau \alpha \sigma i \alpha$ in the Stoic context. Lesses, ${ }^{3}$ Annas $^{4}$ and Sorabji ${ }^{5}$ translate it as "appearance," Frede ${ }^{6}$ and Long \& Sedley ${ }^{7}$ prefer "impression," Inwood \& Gerson $^{8}$ choose "presentation," Long 9 changes his mind afterwards to "representation" in order to avoid any confusion with the Humean concept of impression. In French, Hadot ${ }^{10}$ and Gourinat ${ }^{11}$ render it as représentation. In Italian, Maltese ${ }^{12}$ chooses rappresentazione. In this paper, we will just transliterate it: phantasia.

The notion of phantasia is of fundamental importance to understand Stoic philosophy concerning logical, epistemological and ethical issues. Although

3. Glenn Lesses, Content, Cause and Stoic Impressions. Phronesis XLIII/1 (1998): 2-24.

4. Julia Annas, Hellenistic Philosophy of Mind (Berkeley, University of California Press, 1991).

5. Richard Sorabji, Perceptual Content in the Stoics. Phronesis XXXV/3 (1990): 307314.

6. Michael Frede, "Stoics and skeptics on clear and distinct impressions," in Skeptic Tradition, ed. M. Burnyeat (Berkeley: University of California Press, 1983), 65-93.

7. Anthony Long, \& David Sedley, Hellenistic Philosophers, vol. I (Cambridge: Cambridge University Press, 1987a) \& Anthony Long, \& David Sedley, Hellenistic Philosophers, vol. II (Cambridge: Cambridge University Press, 1987b).

8. Brad Inwood, \& Lloyd P. Gerson, Hellenistic Philosophy: Introductory Readings (Indianapolis: Hackett Publishing Co., 1988).

9. Anthony Long, "Representation and the self in Stoicism," in Companions to Ancient Thought 2: Psychology ed. Stephen Everson (Cambridge: Cambridge University Press, 1991), 102-120.

10. Pierre Hadot, Manuel d'Épictète, trans. Pierre Hadot (Paris: LGF, 2000).

11. Jean-Baptiste Gourinat, Premières leçons sur Le Manuel d'Épictète (The first lessons of Epictetus' Manual) (Paris PUF, 1998).

12. Enrico Valdo Maltese, Epictetus. Manuale (Milan: Garzanti, 1990). 
Cleanthes and Chrysippus consider phantasia a modification of the rational capacity, they differ in explaining this change. To Lesses ${ }^{13}$ Chrysippus seems to criticize Cleanthes for accepting a naïve conception of mental phantasia, according to which perceptual phantasiai are copies of qualities of represented objects (cf. DL ${ }^{14} 7.50 .4$ ). Furthermore, Annas ${ }^{15}$ understands that it is supposed, in the observations of Chrysippus, that phantasiai are articulated in propositional or linguistic form. Thus, Chrysippus' conception of phantasia has two sides: on the one hand, a corporeal one, since it is a modification of the rational capacity, ${ }^{16}$ on the other hand, an incorporeal one, since this modification is associated with an axioma ${ }^{17}$ which describes and evaluates what affects the rational capacity. ${ }^{18}$ This duality is expressed by Chrysippus through his analogy between phantasia and light: as light shows itself and the things illuminated, also phantasia shows itself and the thing that produced it (cf. Aëtius, 4.12.1-5).

For the Stoics, conceptual thinking arises from the occurrence of sensible phantasiai (cf. DL ${ }^{19} 7.49, \mathrm{AM}^{20} 8.56$ ). Therefore, concepts are for them a kind of phantasia, which is created by the internalization of repeated and similar sensible phantasiai. Assent (synkatathesis) is necessarily involved in human apprehension (cf. DL ${ }^{21}$ 7.49, Cicero, Academics 1.40, 2.14522). In rational animals, giving assent to a phantasia is a voluntary act, resulting from the acceptance of a dogma (that we can render in English either as "opinion" or "belief") or hypolepsis (that we can render as "assumption", being in fact synonymous with dogma in Epictetus, as we will see in the fourth section of this paper).

Logically speaking, the assent is given to an axioma, which is defined as "a complete lekton ${ }^{23}$ that can be asserted in what concerns itself". Diogenes

13. Glenn Lesses, Content, Cause and Stoic Impressions, 6.

14. Diogenes Laertius, Lives of Eminent Philosophers, vol. I, II. trans. Robet. Drew Hicks (Harvard: Loeb Classical Library, 1925).

15. Annas, Hellenistic Philosophy of Mind, 74-75.

16. Cf. DL 7.49, AM 8.56.

17. The Stoic equivalent of the proposition of contemporary logic. Cf. DL 7.65. Concerning the incorporeal status of the axioma and also its definition, see next paragraphs.

18. Cf. Glenn Lesses, 1998, p. 6; DL, 7.50.4.

19. Diogenes Laertius, Lives of Eminent Philosophers.

20. Sextus Empiricus, Against the Professors, trans. R. G. Bury (Harvard: Loeb Classical Library, 1949).

21. Diogenes Laertius, Lives of Eminent Philosophers.

22. Cicero, On the Nature of the Gods. Academics, trans. Harris Rackham (Harvard: Loeb Classical Library, 1933).

23. Cf. HP 2.104, DL 7.65.4-5. This Greek word is a verbal adjective of the verb lego (to say) and literally it means "what can be said" and can be understood as the 
Laertius $^{24}$ notes that the word axioma is derived from the verb axioo, which means primarily the "act of acceptance or rejection" (DL 25 7.65). In fact, axioma could be rendered in English as "what is asserted". Axiomata are the only entities that are primarily true or false (cf. $\mathrm{AM}^{26} 8.74,8.12$, $\mathrm{DL}^{27} 7.65-66$ ), being true when it is the case or false otherwise. (cf. $\mathrm{AM}^{28} 8.10,85 ; 88$ ).

As has been noted by Shields, ${ }^{29}$ Stoic orthodoxy proclaims three fundamental views about phantasiai and axiomata: (1) phantasiai can be called true or false (cf. AM ${ }^{30} 7.242-46$ ); (2) only axiomata are, strictly speaking, true or false (cf. $\mathrm{AM}^{31}$ 8.74); (3) no phantasia is an axioma, since phantasiai are impressions or modifications of the mind, while axiomata are lekta and, therefore, incorporeal (cf. AM $\left.{ }^{32} 7.74,7.151-57\right)$. We can thus deduce from these views that a phantasia can be called true or false as long as it contains either a true or a false axioma.

meaning of the words. Lekton is the effect of the process of thinking about what caused a perception. As an effect, it is called an incorporeal by Stoics (on Stoic causality, cf. LS (volume 1), p. 164-5, 169, 199, 271-2, 333-43, 387-8, 393). It is also the distinctive mark of a rational phantasia, by which it can be linguistically articulated. In other words, a lekton (and consequently an axioma) is not something by itself, it does not exist per se, but it subsists according to a rational phantasia (cf. AM 8.70 (=SVF, 2.187)). Lekton is objective as long as it refers to a certain attribute of a body. But, as a property of a phantasia, which, as we said above, is a modification of rational capacity and something corporeal, it subsists only subjectively (LS 27D). There are many types of lekta, but, for the purposes of the present investigation, we will concentrate our attention on the axioma.

24. Diogenes Laertius, Lives of Eminent Philosophers.

25. Ibid.

26. Sextus Empiricus, Against the Professors.

27. Diogenes Laertius, Lives of Eminent Philosophers

28. Sextus Empiricus, Against the Professors.

29. Christopher Shields, "The truth evaluability of stoic phantasiai: adversus mathematicos VII 242-46," Journal of the History of Philosophy 31 no. 3-July 1(1993): 325.

30. Sextus Empiricus, Against the Professors.

31. Ibid.

32. Ibid. 


\section{Encheiridion 1.5 and Phainomenon}

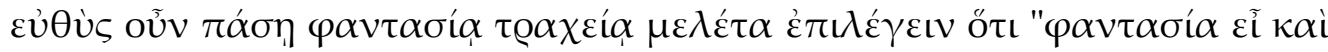

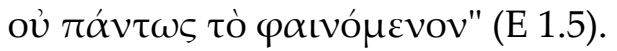

The first commentary available about E 1.5 is the one of Simplicius ${ }^{33}$ (Commentary to Epictetus' Encheiridion, 20.1 ff.), who tells us that Epictetus "calls tracheiai those phantasiai" that have the power of causing damage to our minds, because "they are irrational and frantic, and genuinely make life rough for the asymmetry and the anomaly of their movements" 34 . Simplicius precisely identifies what kind of phantasiai he is referring to: the ones of desire (orektike) or aversion (ekkletike) to something external and not subjected to choice (that is: things not up to us - ouk eph'hemin), noting that Epictetus recommends that, whenever such a phantasia arises, we must dissolve its vehemence reflecting that it is nothing but a phantasia. Next, Simplicius says that, among phantasiai, some reveal the truth, while others are nothing but vain illusions. The former are truly beneficial or enjoyable, while the latter are harmful or painful.

After Simplicius, we have the Latin translation of Niccolò Perotto (1450), who renders E 1.5 in this way: "Omni tuae imaginationi fac discas confestim ita dicere: 'imaginatio es; non id es quod videris"' ("Learn to say promptly to every phantasia of yours: 'You are a phantasia, not what you seem to be"').

Next, the famous Latin translation of Angelus Politianus (1479):35 "Continuo igitur in quavis aspera imaginatione disce considerare imaginationem esse illam neque id omnino esse quod videtur" ("In this way, learn continuously, in relation to any harsh phantasia, to consider it a phantasia, and not at all what it seems to be").

We must also mention Schweighäuser's translation (1799-1800):36 "Statim igitur omni aspero viso responsar estude, ac dicere: 'visum est ac nullo modo id quod esse videris"' ("In this way, promptly answer and say to every harsh phantasia: 'You are a phantasia and not at all what you seem to be"').

33. Simplicius, Simplicius on Epictetus: Handbook 1-26, trans. Charles Brittain (Ithaca: Cornell University Press, 2002).

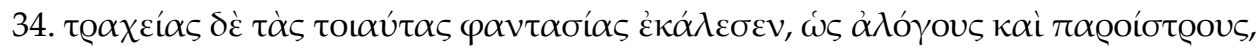

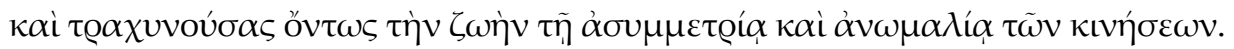

35. Completed in 1479, but published for the first time in 1528. Angelus Politianus, Epicteti Stoici Enchiridion et Graeco interpretatum ab Angelo Poliziano (Stoic Epictetus' Enchiridion interpreted by Angelus Polician) (Veneza: J. Anthonium et Fratres de Sabio, 1528).

36. Johann Schweighäuser, Epicteteae Philosophiae Monumenta. 5 volumes (Leipzig: Teubner, 1799-1800). 
Oldfather ${ }^{37}$ renders the line in the following manner: "Make it, therefore, your study at the very outset to say to every harsh external impression: 'You are an external impression and not at all what you appear to be'".

White ${ }^{38}$ translates the line as follows: "From the start, then, work on saying to each harsh appearance, 'You are an appearance, and not at all the thing that has the appearance'".

Gourinat, ${ }^{39}$ in turn, translates thusly: "Donc, dês qu'une phantasia pénible se forme, prend soin de dire aussitôt: 'Tu es une phantasia, et pas du tout ce que tu représentes'" ("So, when a painful phantasia arises, be careful to say promptly: 'You are a phantasia, and not at all what you represent'").

Finally, we must also mention Boter's ${ }^{40}$ translation: "Therefore you should do your best from the outset to say to every harsh impression, 'You are an impression, and not at all what you seem to be."'

Summing up Simplicius' ${ }^{41}$ commentary and these translations, we can see two fundamental possibilities for rendering the second sentence of Encheiridion 1.5: (1) "You are a phantasia, and absolutely not what you represent" (Simplicius, Gourinat, White); (2) "You are a phantasia, and absolutely not what you seem to be" (Perotto, Poliziano, Schweighäuser, Oldfather, Boter).

Note that, strictly speaking, these two options can be seen as merging into one. As have been stated above, Chrysippus' analogy between phantasia and light implies that phantasia shows itself and the thing that produced it; therefore, "what a phantasia seems to be" or "what a phantasia represents" can have the same meaning and can render phainomenon equally well.

Nevertheless, Hadot, ${ }^{42}$ in his translation of Epictetus' Encheiridion (2000), conducts an in-depth assessment of the rendering of phainomenon in E 1.5. Previously, in La citadelle intérieure, ${ }^{43}$ after discussing Goldschmidt's translation of E $1.5,{ }^{44}$ Hadot criticizes it, saying that:

37. William Abbott Oldfather, Epictetus. The Discourses of Epictetus as reported by Arrian; Fragments; Encheiridion (Harvard: Loeb, 1928), 485.

38. Nicholas White, Epictetus. Epictetus, The Handbook, the Encheiridion (Cambridge: Hacket, 1983), 12.

39. Jean Baptist Gourinat, Premières leçons sur Le Manuel d'Épictète, 91.

40. Gerard Boter, Epictetus. The Encheiridion of Epictetus and its Three Christian Adaptations (Leiden: Brill, 1999), 278.

41. Simplicius, Simplicius on Epictetus: Handbook 1-26,

42. Pierre Hadot, Manuel d'Épictète.

43. Pierre Hadot, La citadelle intérieure: Introduction aux Pensées de Marc Aurèle (The inner citadel: Introduction to the Meditations of Marcus Aurelius) (Paris: Fayard, 1992), 129.

44. "Tout de suite, en présence de chaque représentation pénible, exerce-toi à dire à son sujet: Tu n'es qu'une représentation, et pas tout à fait ce que tu representes" (Victor Victor Goldschmidt, Le Système stoïcien et l'idée de temps (The Stoic system and the idea of time) (Paris: Vrin, 1977), 120-121). 
Goldschmidt did not see that the activity of the subject, for Epictetus and Marcus Aurelius, does not consist in the production of an objective or comprehensive phantasia, but in clinging to an objective phantasia without adding a moral judgment that would deform this phantasia. (Hadot, ${ }^{45} \mathrm{D}$ 3.12.15046).

However, in his edition of the Encheiridion, Hadot ${ }^{47}$ translates the line as follows: "So train yourself to add immediately to any painful phantasia: You are just a pure phantasia and you are not in any way what you represent." In the introduction of the work, Hadot carefully analyzes the phrase "You are a phantasia and absolutely not the phainomenon," noting that the first part means: "You are nothing but a simple phantasia and I have the right to doubt you" and mentioning Simplicius'48 interpretation, whereby we must dissolve the violence of a harsh phantasia by means of thinking that it is nothing but a phantasia. ${ }^{49}$

Hadot underlines that, in the Discourses, the Greek word phainomenon has a precise meaning, which appears in D 1.28.10: "to human beings the measure of every act is the phainomenon," meaning here "what seems to us," or "what appears to us." We can say that phainomenon also occurs in the Encheiridion in this sense, for instance, in E 31:

For every animal is formed by nature to this, to fly from, and to turn from the things which appear harmful [blabera phainomena], and the things which are the cause of the harm, but to follow and admire the things which are useful and the causes of the useful. It is impossible then for a person who thinks [oiomenon] that he is harmed to be delighted with what seems [dokounti] to be the cause of the harm, as it is also impossible to be pleased with the harm itself. (E 31.3) ${ }^{50}$

45. Pierre Hadot, La citadelle intérieure, 128.

46. "Goldschmidt n'a pas vu que l'ativité du sujet, pour Épictète et Marc Aurèle, ne consiste pas à produire une représentation compréhensive ou objective, mais précisément à s'en tenir à ce qu'il y a d'objective dans la représentation objective, sans lui ajouter de jugement de valeur qui la déformerait".

47. Pierre Hadot, Manuel d'Épictète, 163.

48. Simplicius, Simplicius on Epictetus: Handbook 1-26.

49. Pierre Hadot, Manuel d'Épictète, 52-53. Hadot adds that "the first reaction facing a phantasia, an interior image that troubles and terrifies us, [...] must consist in giving a time of delay, and adding some words to it", correctly pointing out that the line contains an advice to the practice of aproptosia, which is the Stoic virtue that prevents hasty assent to a phantasia (cf. E 3, 4, 9 and 12; D 2.18.29).

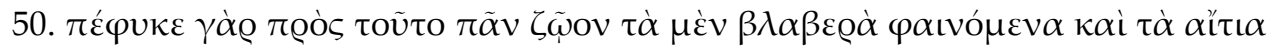

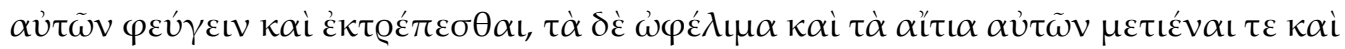

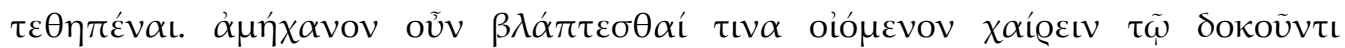


This chapter is particularly important because it links the verbs oiomai, dokeo and phainomai (through its participle phainomena). In fact, there is an interconnection between these verbs in Epictetus.

Oiomai occurs several times with the meaning of "to think, to suppose, to believe." 51 The same with dokeo, that occurs meaning something like "to seem to be the case." See, for instance, the imaginary dialogue between Zeus and Epictetus: after saying to the latter that he gave him the faculty of using phantasiai, Zeus asks: "Do these seem [dokei] to you small matters?" (D 1.1.13).52

As for phainomai, its sense is clearly stated when Epictetus tells us, in D 1.27: "phantasiai are to us in four ways: for either things appear (phainetai) as they are; or they are not, and do not even appear to be; or they are, and do not appear to be; or they are not, and yet appear to be."53

E 42 provides further confirmation of the interconnection between oiomai, dokeo, phainomai and also hypolambano in Epictetus:

When any person treats you ill or speaks ill of you, remember that he does this or says this because he thinks [oiomenos] that it is his duty. It is not possible then for him to follow that which seems to be the case to you [phainomenoi], but that which seems to be the case to himself. Accordingly, if he is wrong about what seems to be the case [phainetai] to himself, he is the person who is hurt, for he is the person who has been deceived; for if a human being shall suppose [hypolabei] the true conjunction to be false, it is not the conjunction which is hindered, but the human being who has been deceived about it. If you proceed then from these, you will be mild in temper to him who reviles you: for say on each occasion, "It seemed [edoxen] so to him." 54

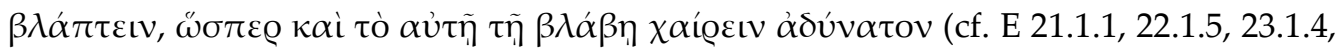
$33.10 .3,33.10 .8,34.1 .8,40.1 .7,42,51.2 .2)$. In this paper, when quoting Epictetus, we will use slightly modified versions of George Long's translations of Epictetus' Discourses and Encheiridion.

51. Cf. D 1.5.5.4, 1.17.18.4, 1.20.10.2, 2.17.3.2, etc.

52. Cf. D 1.2.18.2, 1.2.21.1, 1.9.15.2, 1.9.27.2, 1.11.5.1, 1.11.12.2, 1.11.12.4, 1.11.17, 1.11.18.2, 1.11.32.3, 1.12.12.1, 1.12.19.3, 1.14.2.1, 1.14.3.1.

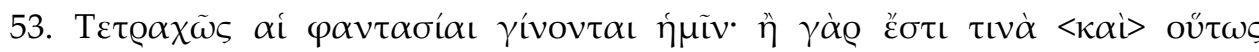

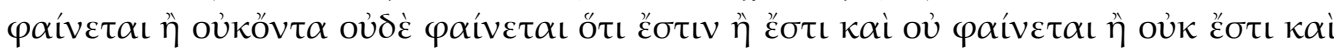

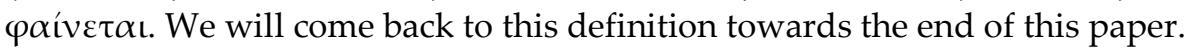

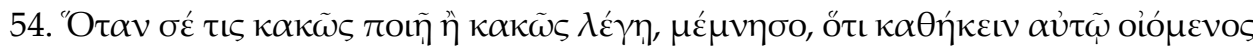

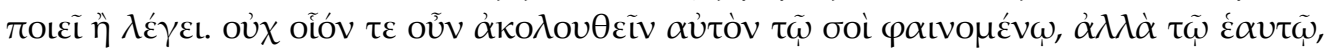

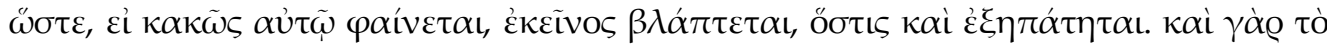

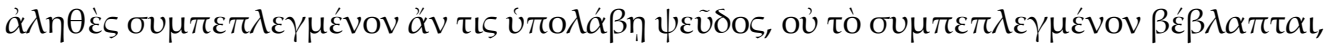

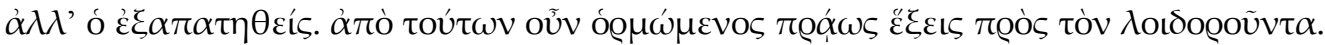

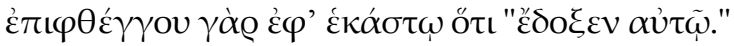


In brief, the verbs phainomai and dokeo are synonymous in Epictetus. Oiomai and hypolambano (which occurs in Epictetus meaning "to suppose"55) are closely related to them, and phainomenon, a participle of phainomai, has the meaning of "what seems to us" or "what appears to us." 56

However, in E 1.5, Hadot believes that phainomenon means something different: the object as represented in a comprehensive phantasia:

The interpretation I offered elsewhere ${ }^{57}$ of our line was very different from the one I offer now. Instead of translating phainomenon as "the object as it presents itself in the harsh representation" [...] I translate this word, following Bonhöffer, ${ }^{58}$ as "the object as it really presents itself" [...] the object as it represents itself in an objective, comprehensive, adequate phantasia. ${ }^{59}$

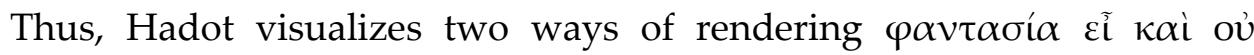

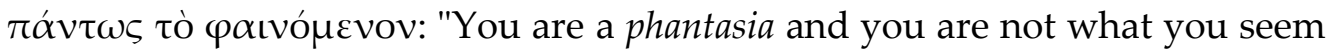
to be," in which the word phainomenon means the object as presented in the harsh phantasia, and "You are a phantasia and you are not what the object really is in the comprehensive phantasia," in which phainomenon means the same object as represented in the objective phantasia. This last option, elected by him as the correct one, can be seen as equivalent to the choice (1) pointed above: "You are a phantasia, and absolutely not what you represent." We will come back to this issue at the end of this paper, in order to evaluate if Hadot is right about it or not.

55. Cf. D 1.3.4.3, 1.25.9.1, 1.25.12.1, etc.

56. In addition, Epictetus uses frequently the verb phantazo, meaning "to have the phantasia of" or "to imagine," in a sense close to the verb dokeo. For instance, in D 1.5.6.2, our Stoic says: "When in my sleep I imagine (phantazomai) that I am awake" (cf. D 1.18.13.3, 1.30.6.1, 2.10.27.2, 2.14.7.2, 2.14.9.1, 2.14.18.3, 2.15.1.4, 2.16.23.1, 2.16.23.1, 2.21.4.4, 2.21.6.2, 2.21.7.3, 2.26.4.1, 3.22.11.1, 3.22.12.1, 3.22.39.34-5, 3.22.80, 4.1.33.3, 4.1.135.2, 4.11.25.5, 4.12.1.3). Sometimes, the word phantasia itself is used in this sense (cf. D 2.26.5.3, 2.20.29.6, 4.1.174.4).

57. The one presented above, from La citadelle intérieure (1992).

58. Adolf Bonhöffer, Epictetus und die stoa (Epictetus and the stoa) (Stuttgart, 1890), 143.

59. Pierre Hadot, La citadelle intérieure:, 54. "L'interprétation que j'avais donnée ailleurs de notre formule était assez diferente de celle que je propose maintenant. Au lieu de traduire to phainomenon par 'l'objet tel qu'il se presente dans la représentatio pénible' [...] Je traduisais ce mot, à la suite de Bonhöffer, par 'l'objet tel qu'il se presente réellment' [...] l'objet tel qu'il se presente dans la représentation adéquate, objective et compréhensive." 


\section{Phantasia in Epictetus}

In Epictetus, phantasia's most fundamental link is with the rational capacity (dynamis logike), which, in D 1.1.5.3, is described as the one which makes use of phantasiai and the only one which is self-evaluative. ${ }^{60}$ In D 1.20.16.1, Epictetus establishes the nature (ousia) of human good as "a proper use of phantasiai"61 and, in D 3.1.25.2, human being is defined as a mortal animal which has the power of using phantasiai rationally. ${ }^{62}$ Thus, the rational capacity makes use of phantasiai, and the proper use of phantasiai, namely the rational, is the very nature of human good. ${ }^{63}$

Furthermore, the rational capacity is the only one given by the gods which is totally up to us (eph'hemin - D 1.1.7.364), being an authentic part of Zeus in us - a capacity that, if well exercised, leads us to imperturbability (D 1.1.12.565). From this we deduce that the proper use of phantasiai, the main function of the rational capacity, is also totally up to us.

All these views prove the centrality of the rational capacity to human beings, and also the centrality of the concept of phantasia in Epictetus, as the rational capacity is, strictly speaking and first of all, a capacity for rationally using phantasiai. Since this use constitutes the human good, the good human (namely the human being who attains her own good) is the one who makes

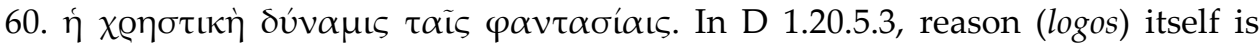

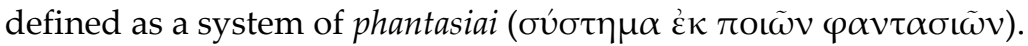

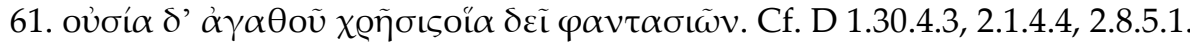

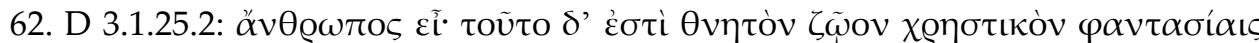
$\lambda$ o $\gamma(\kappa \tilde{\omega} \varsigma$. In D 3.3.2.1, our Stoic adds that "the business of the wise and good human

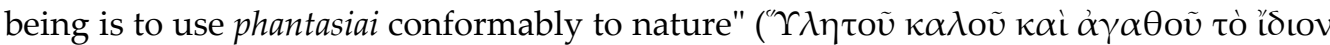

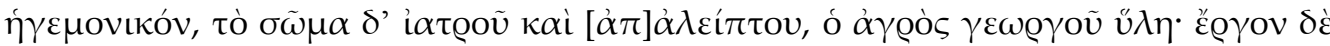

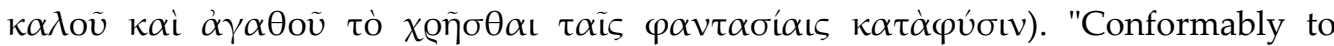
nature" means, of course, the same as "rationally." Cf. D 3.16.15.3.

63. Concerning the use of reason in Stoicism in general (Thomas Benatouil, Faire usage, la pratique du stoïcisme (Make use, the practice of stoicism) (Paris: Vrin, 2006), 65.

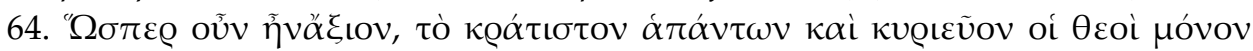

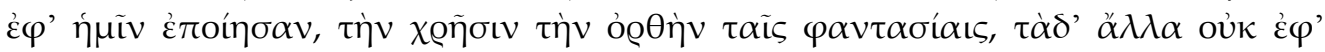
$\eta \mu \tilde{\nu}$. Cf. Epictetus, fragment 4.5.

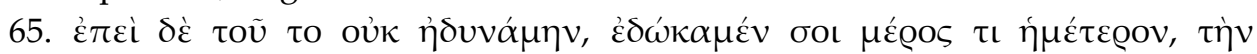

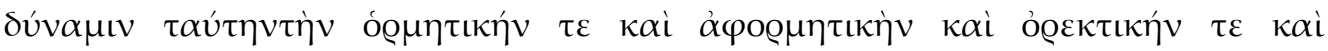

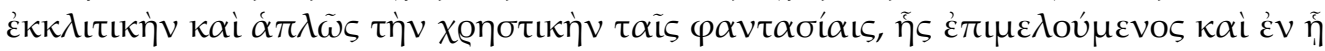

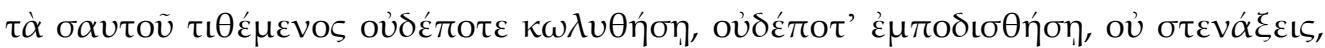

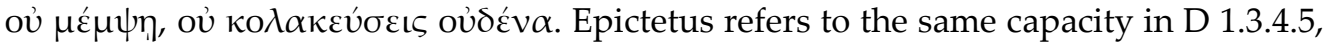
1.6.13.4, 1.6.18.5, 1.12.35.1, 1.20.5.2, 1.28.12.1, 2.8.4.2, 2.8.6.2, 2.8.7.4, 2.8.8.3, 2.8.21.1, 2.14.15.4, 2.19.32.4, 2.22.5.3, 2.22.29.3, 2.23.8.1, 2.23.40.3, 2.23.42.2, 3.1.26.1, 3.21.23.7, 3.22.21.1, 3.22.103, 3.24.69.2, 4.1.75.1，4.4.28.3，4.5.23.3，4.6.26.1，4.6.34.3，4.7.32.7， 4.10.13.4, 4.10.26.4. 
proper use of phantasiai, while the bad human being does the opposite. Attaining human good through the proper use of phantasiai, in turn, results in imperturbability. Therefore, the improper use of phantasiai results in mental turbulence, and that is the reason why, in the Encheiridion, our Stoic explains many times the need of being aware so that the harsh phantasiai do not carry us along with them. ${ }^{66}$ Indeed, Epictetus refers several times to phantasiai that trouble the mind, causing damage to it, ${ }^{67}$ and talks about bad people subdued by phantasiai, ${ }^{68}$ as well as about Medea as the paradigm of someone who is enslaved by the phantasia of revenge. ${ }^{69}$

The prescription "We must be aware of harsh phantasiai that can disturb the mind" is, by its turn, followed by a series of ethical teachings by which the impact of such phantasiai can be lessened. D 2.18 and 3.8, for instance, are, in their totality, about this subject. In D 2.18.24.2, we find the paragraph from which Arrian took E 1.5. After talking about how to prevail over a certain kind of phantasia, Epictetus declares:

But in the first place be not hurried away by the rapidity of the phantasia, but say, "Phantasia, wait for me a little: let me see who you are, and what you are about: let me put you to the test."70

In fact, elsewhere, Epictetus notes that "it is the chief and the first work of a philosopher to examine phantasiai, and to distinguish them, and to admit none without examination" (D 1.20.7.2) $)^{71}$ and that we must test them all (D 3.26.13.7). ${ }^{72}$ This test is obviously linked to the proper use. But here we can ask: what does the proper use of phantasiai consist of? What does the test of a phantasia consist in? To formulate answers to these questions, let us turn our attention to D 3.3.21.1, where Epictetus introduces us to an analogy concerning the relationship between the mind and its phantasiai:

66. Cf. E 10.1.6, 18.1.2, 19.2.3, 20.1.4, 34.1.1.

67. Cf. D 1.26.10.3, 2.16.20.4, 2.16.20.4, 2.22.6.2, 3.22.25.5, 3.22.29.1.

68. Cf. D 2.22.25.2.

69. Cf. D 2.17.19.3.

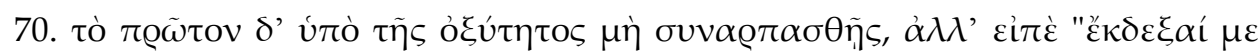

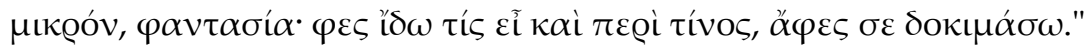

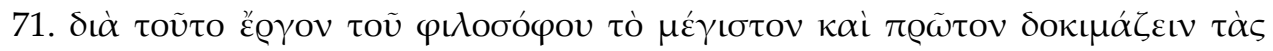

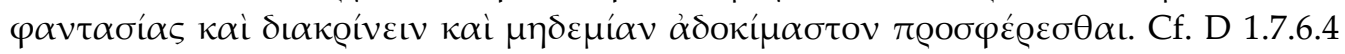
ff., 1.20.7 ff., 2.23.8.4.

72. Epictetus teaches us also that "at the times when you are delighted with a thing, place before yourself the contrary phantasiai" (D 3.24.88.2); that we must resist certain phantasiai (D 3.2.8.3, 3.25.6.1); that we must fight against some phantasiai (D 3.24.108.1). Doing so also requires practice and exercise as well (D 3.12.6.4, 4.4.26.4 - cf. D 4.3.7.1). 
Such as is a dish of water, such is the soul. Such as is the ray of light which falls on the water, such are the phantasiai. When the water is moved, the ray also seems [dokei] to be moved, yet it is not moved. And when a human being is seized with giddiness, it is not the arts and the virtues which are confounded, but the rational capacity on which they are impressed; but if the rational capacity be restored to its settled state, those things also are restored..$^{73}$

The analogy is self-evident: such as the ray of light seems to be moved when water is moved, such is the phantasia regarding soul. Phantasia cannot move the mind by itself. It is the dogma (which subsists according to the phantasia) about the external object that caused the perceptual content of the phantasia that moves the mind.

In fact, when we give assent to an axioma that subsists in a certain phantasia, this axioma becomes our dogma (our "opinion" or "belief") about the thing that caused the perceptual content of the phantasia. Dogmata are the entities that have to be doubted and tested, insofar as it is up to us to give assent to them or not. But, again, what does the test of a phantasia consist of? To answer this, let us turn our attention to $\mathrm{E} 1$ :

Of things some are in our power, and others are not. In our power are assumption (hypolepsis), impulse (horme), desire (orexis), aversion (ekklisis); and, in a word, whatever are our own acts: not in our power are the body, property, reputation, offices, and, in a word, whatever are not our own acts. And the things in our power are by nature free, not subject to restraint $[\ldots]$, but the things not in our power are [...] subject to restraint, in the power of others. Remember then that if you think the things which are by nature slavish to be free, and the things which are in the power of others to be your own, you will be hindered [...], but if you think that only what is your own to be your own, and if you think that what is another's, as it really is [...], no human being will ever compel you, [...] you will do nothing involuntarily [...] you will not suffer any harm. ${ }^{74}$

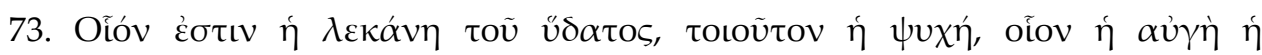

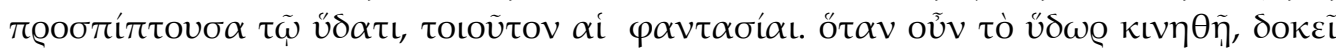

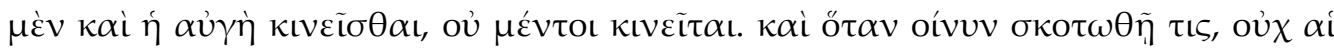

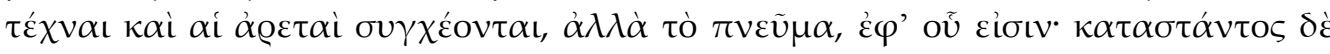

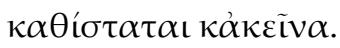

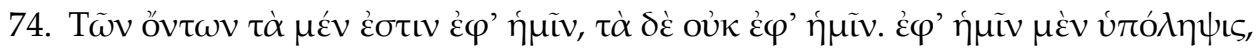

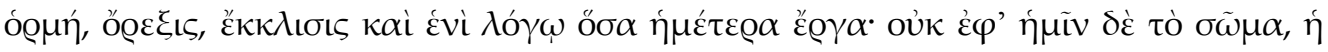

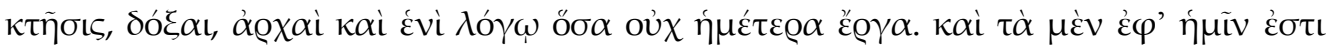

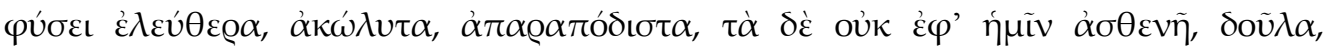

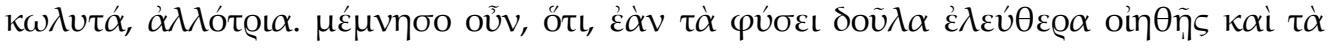


From this, it is clear that if we busy ourselves with what is up to us, then we will not disturb ourselves; but if we consider other people's things as ours, or if we want to control things that ultimately are not in our power, then we will get disturbed. We must understand E 1.5 in this context, since in the continuation Epictetus advises the reader of the Encheiridion to apply the fundamental distinction between things up to us and things not up to us to every harsh phantasia:

Then examine it by the rules which you possess, and by this first and chiefly, whether it relates to the things which are in our power or to things which are not in our power: and if it relates to anything which is not in our power, be ready to say that "You are nothing to me." (E 1.5.3)

Thus, we can conclude that the primary objective of saying "You are a phantasia and in no way what you seem to be" is to make a distinction between the content of a perception and how it is evaluated. Through this distinction the perceptual content of the phantasia is distinguished from the evaluation of it - in short: a certain dogma held about the thing represented. If something is not up to us, we must understand that it is not by itself good or bad, and, therefore, that it is nothing to us, which leads us to the conclusion that our suffering about the thing, by which its phantasia seems harsh to us, is solely caused by a certain dogma, which wrongly evaluates the impression of something external. To make the emergence of the comprehensive phantasia (which is totally in agreement with the correspondent external object) possible, this dogma must be withdrawn.

Therefore, when Epictetus states that we need to test phantasiai, he means testing a certain dogma, our opinion or belief about what caused the perceptual content of the phantasia. When confronting a harsh phantasia, we must apply the first test: verify if it concerns something up to us or not. In the case of it not being something up to us, we should say promptly: "It's nothing to me." Therefore, the priority target of this test is the harsh phantasia, which is able to trouble the mind. This phantasia has not, by itself, the power of troubling the mind. As we have seen through the analogy of sun light, it is a certain dogma or hypolepsis about what caused the perceptual content of the phantasia that moves the mind.

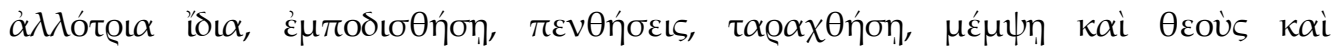

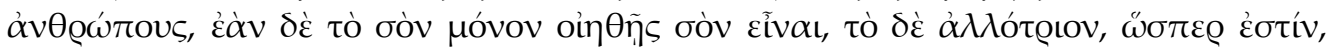

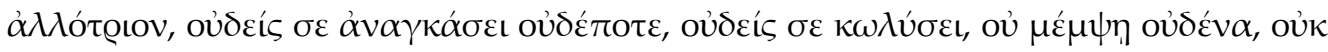

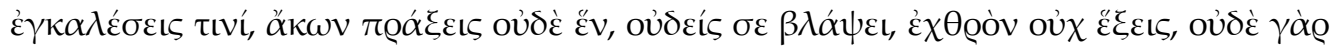

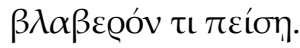

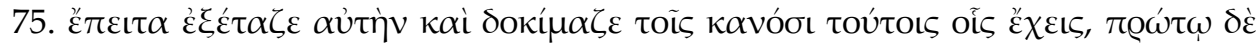

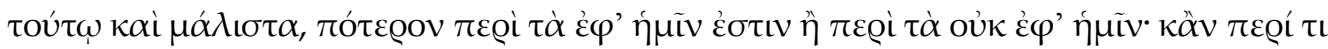

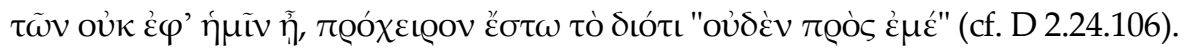




\section{Dogma and Hypolepsis}

Concerning dogmata, we must note that it is in Epictetus, first of all, a general concept, since our Stoic qualifies as dogma any opinion or belief held by reason, whether good or bad, philosophical or not. ${ }^{76}$

For our purposes here, the most relevant division is between good (or right) and bad (or wrong) dogmata, which are in straight relation with good and bad actions. In fact, in D 3.9.2.4, Epictetus highlights: "if you have right dogmata, you will fare well; if they are false, you will fare ill,"77 since "to every human being the cause of his acting is dogma" (D 3.9.3.1). ${ }^{78}$ Besides, good dogmata confer safeness, since only good dogmata can render a human being secure and impregnable (D 4.5.26.2).

Bad or wrong dogmata, in turn, are the cause of restlessness and disturbance in the human mind. As Epictetus points out in $\mathrm{E} 5 \mathrm{a}$ :

Human beings are disturbed not by the things [ta pragmata], but by the opinions [dogmata] about the things: for example, death is nothing terrible, for if it were, it would have seemed [ephaineto] so to Socrates; for the opinion [dogma] about death, that it is terrible, is the terrible thing. When then we are impeded or disturbed or grieved, let us never blame others, but ourselves, that is, our opinions $[\text { dogmata }]^{79}$.

The sense of the passage is clear: what causes trouble is not the external thing, but the dogma held about the external thing (as being something good or bad), since bad or wrong opinion causes trouble, turbulence. ${ }^{80}$ In E 16, Epictetus returns once more to this issue:

76. For instance, in D 3.7.9.1, Epictetus refers to Epicurus and his dogmata. In D 3.7.17.2, Epictetus warns that only someone who follows the dogmata of Stoicism can be properly called Stoic (cf. D 3.7.20, 3.7.22.1, 3.24.38.3, 4.1.170.1, 4.1.177.1).

77. Cf. D 4.8.3.4.

78. Good or right dogmata are adequate guides for action. In D 2.19.10 ff., for instance, Epictetus states that we benefit from reading a philosophical work acquiring from it good dogmata that can guide us. This explains why, in D 3.10.1.1, Epictetus stresses that we must have at hand the proper dogmata for each occasion. In D 2.20.26.9, Epictetus asserts that the greatness of Sparta, on whose behalf the three hundred warriors died in the battle of Thermopylae, is due to the dogmata held by them.

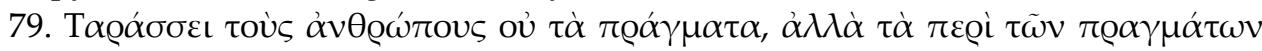

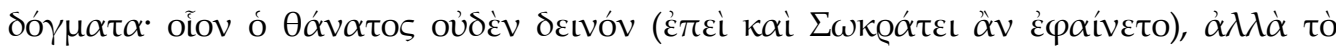

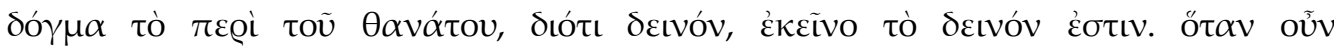

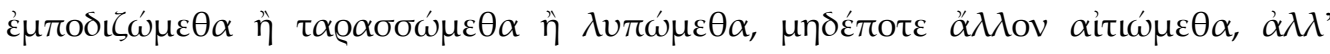

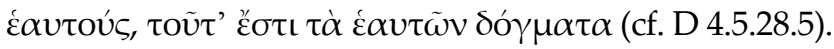

80. The view according to which opinions directly relate to restlessness and anxiety is restated several times (cf. D 1.19.8.2, 1.25.29.1, 3.19.3.3, 3.22.61.4, 4.1.58.2). 
When you see a person weeping in sorrow either when his child goes abroad or when he is dead, or when the man has lost his property, take care that the phantasia does not hurry you away with it, as if he were suffering in external things. But straightway make a distinction in your own mind, and be in readiness to say, "It is not that which has happened [to symbebekos] that afflicts this man, for it does not afflict another, but it is the dogma about this thing which afflicts the man." 81

In E 20, the same view is expressed referring to offenses: "Remember that it is not he who reviles you or strikes you who insults you, but it is your dogma about these things as being insulting." 82 This chapter is especially important, since it is where Epictetus asserts the identity between dogma and hypolepsis saying: "When then a human being irritates you, you must know that it is your own assumption [hypolepsis] which has irritated you."83 In E 1, Epictetus points out that hypolepsis is among things up to us. As hypolepsis and dogma are synonymous in Epictetus, the same thing can said about dogma.

But why is a dogma good (right) or bad (wrong)? The answer is that good (right) dogmata add value to the self and withdraw value from external things, while bad (wrong) dogmata add value to external things and withdraw value from the self. Dogmata are measured by the way they evaluate things: bad dogmata evaluate external things (which are not up to us) as good or bad; good dogmata evaluate external things as indifferent; bad dogmata underrate internal things (which are up to us); good dogmata evaluate internal things as good or bad.

Thus, in D 1.3.1.1, the idea that all human beings are children of Zeus is called a dogma, which allows the one who gives assent to it not to think anything abject about himself. ${ }^{84}$

In D 3.3.18.2, in turn, Epictetus highlights that suffering is caused by a dogma according to which something external is good (and therefore desirable) or bad (and therefore avoidable). Also, in D 1.19.16.1, Epictetus

Epictetus also notes that the most fortunate man becomes the most unfortunate if he does not hold good opinions (cf. D 4.10.36.4).

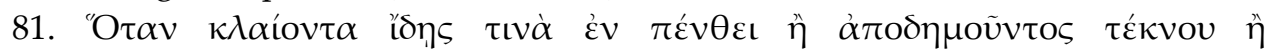

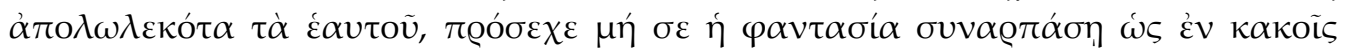

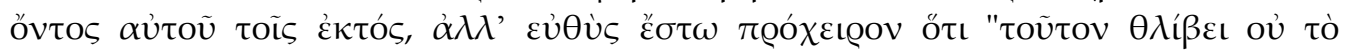

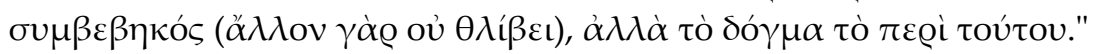

82. Cf. D 4.5.29.2.

83. Cf. D 2.6.21.1, 2.9.14.2, 2.14.22.3, 3.16.9.2, 3.16.11.1, 3.16.13.2, 4.6.14.3, E. 1.1.2, 20.1.3, 31.1.2.

84. On this subject, see also D 1.18.20.1. Good dogmata are also the only way to overcome a tyrant (D 4.1.86.3). 
points out that the cause of servitude is the dogma according to which things not up to us are good or bad..$^{85}$

Dogmata are closely linked with prohairesis (the human capacity of choice). In D 1.29.3.2, Epictetus says: "for the dogmata about the materials [things which we choose], if the dogmata are right, make the choice good: but perverse and distorted dogmata make the choice bad." 86 In D 1.17.27.1, Epictetus tells us that prohairesis cannot be constrained by anything but itself that is: by the dogma it holds. ${ }^{87}$

Since for Epictetus prohairesis is what we really are, ${ }^{88}$ and it is good only when it holds good dogmata, the destruction of a human being is the destruction of correct dogmata (D 1.28.25.3). In fact, in D 4.7.14.4, Epictetus tells us that our dogmata are our only true possessions, which we carry wherever we go, and which nobody can take from us. ${ }^{89}$

85. In addition, in D 3.24.56.1, Epictetus tells us that "To desire things which are impossible is to have a slavish character, and is foolish: it is the part of a stranger, of a man who fights against God in the only way that he can, by his opinions." In D 2.22.28.1, Epictetus notes that antisocial behaviour in humans is due to the dogmata people hold about what good and bad is. Epictetus finishes this discourse saying that bad dogmata make human beings unable to enjoy true friendship. In fact, in D 3.9.12.3, Epictetus says that dogmata are the basis of real relationships between human beings: "But he meets with a human being as a human being, who learns his dogmata, and in

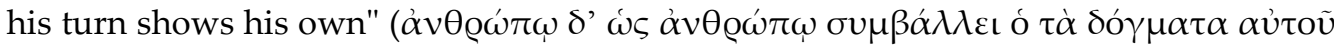

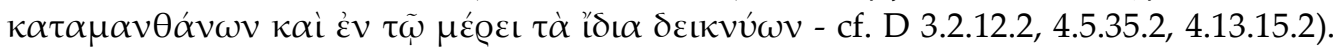
In D 4.5.17, Epictetus remarks that we can evaluate someone's dogmata checking out his character: if he is gentle, sociable, patient and loving, then his dogmata are good; if the opposite is the case, then his dogmata are bad. Finally, in D 1.12.26.4, Epictetus declares that greatness of reason is related to its dogmata.

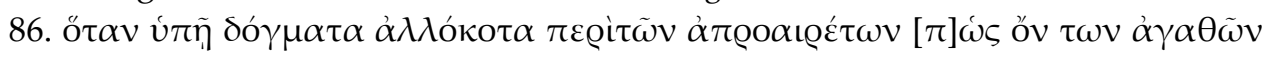

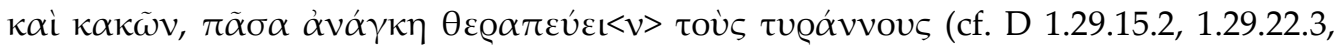
3.24.38.3, 4.6.14.2, 4.6.24.2, 4.6.28.4). D 2.16 is entirely focused on correcting our dogmata by means of the Stoic distinction between good and bad things. Cf. D 3.17.9.2, 3.26.34.2.

87. Cf. D 1.29.12.1.

88. Cf. D 3.1.40-43, 3.18.1-3, 4.5.12.

89. Cf. D 4.7.35.4. This is the reason why it is the work of the philosopher, before anything else, to inspect (episkopeo) and to scrutinize (exetazo) dogmata (cf. D 1.11.38.4, 2.1.32.3, 2.21.15.3, 3.1.43.1, 3.2.13.1, 3.5.42, 3.9.6.6, 3.9.8.1, 4.1.112.3, 4.1.137, 4.11.8.2). Besides that, good dogmata must be exercised (cf. D. 4.1.140.1, 4.6.14.2, fragment 16). 


\section{Conclusion}

Let us summarize what has emerged so far in the course of our investigations. We have seen that rational phantasiai are articulated in propositional or linguistic form, and have two sides: on the one hand, it is a modification of the rational capacity; on the other hand, this modification is associated with an axioma that describes and evaluates what affected the rational capacity. In Epictetus, the rational capacity is described as the one which makes use of phantasiai. Epictetus defines the nature (ousia) of human good as "a proper use of phantasiai,"90 and human being is a mortal animal which has the power of using phantasiai rationally.

Attaining human good through the proper use of phantasiai, in turn, results in imperturbability, and the improper use of phantasiai results in mental turbulence. That is the reason why we need to be careful about harsh phantasiai.

The analogy with the ray of light highlights that phantasia does not move the mind by itself. What in fact moves the mind is a certain dogma about the external object which is the cause of the perceptual content of the phantasia. Therefore, testing phantasiai in Epictetus means testing a dogma, a certain opinion or belief about what caused the perceptual content of a phantasia. Note that we are not reducing phantasia to dogma, but we are saying that testing a phantasia means testing its propositional aspect, what is sayable and up to us in the phantasia: the dogma.

Good (or right) and bad (or wrong) dogmata are in straight relation with good and bad actions. Besides, good dogmata confer safeness, since only good dogmata can render a human being secure and impregnable. Bad or wrong dogmata, in turn, are the cause of restlessness in the human mind.

Dogmata are measured by the way they evaluate external things: bad dogmata evaluate external things as good or bad and underrate internal things; good dogmata evaluate external things as indifferent and evaluate internal things as good or bad.

Dogmata are closely linked with prohairesis, since they are the materials on which prohairesis works. Prohairesis is what we really are, and it is good only when it holds good dogmata.

Thus, the tracheia phantasia of E 1.5, difficult to handle and contrary to reason as it is, contains a bad dogma that must be eliminated in order to bring back serenity. What seems to be the case (the phainomenon), which is strictly speaking, a dogma, must be scrutinized and tested and, in the case of a harsh phantasia, must be eliminated.

In order to banish bad dogmata and welcome good ones in our minds, we must apply, first of all, the rule expressed in the first chapter of the

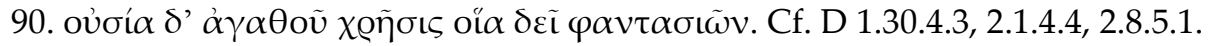


Encheiridion. If it is about something external, we must understand that it is not up to us and, consequently, not a good or a bad thing.

Now, to come back to the question about Hadot's interpretation of E 1.5, we can say that phainomenon there means, as in all Epictetus' works, "what seems to be the case." As Hadot points out in La citadelle intérieure, Epictetus does not say that we must produce a comprehensive phantasia, but we must keep our phantasiai comprehensive without adding to them false dogmata. To keep phantasiai of external things comprehensive, we must not add value to them, we must reduce the dogma contained in them to their perceptual content. Epictetus explicitly expresses it, for instance, in E 45:

Does a man bathe quickly? Do not say that he bathes badly, but that he bathes quickly. Does a man drink much wine? Do not say that he does this badly, but say that he drinks much. For before you shall have determined his dogma, how do you know whether he is acting wrongly? $?^{91}$

These examples, applications of the rule expressed in E 1, are clear: if I see a man bathing quickly, I must not add to this perception the dogma "He is bathing badly"; If I see a man drinking much wine, I must not add to this perception the dogma "He is drinking badly," since I do not know why he is doing such things.

We have seen other instances of it above. In E 5, Epictetus points out that we must not add, to the phantasia of someone's death, that it is terrible. ${ }^{92} \mathrm{In} \mathrm{E}$ 20 , the same is said about insults.

In all these cases the same thing happens: it is not the phantasia that disturbs our minds, but it is a dogma that seems right to us (the phainomenon), wrongly added to the phantasia by ourselves, that falsifies it. The harsh phantasia is not harsh because it contains by itself a false dogma, but because we mistakenly add to the phantasia a false dogma that seems to us to be the case. And in order to keep our minds filled with comprehensive phantasiai (and consequently to keep our minds in accordance to nature and in serenity), we must not lower our guard and we must continue to be constantly vigilant regarding every harsh phantasia.

Now, we can explain clearly what the harsh phantasia mentioned by Epictetus in E 1.5 is. As we have seen, Simplicius ${ }^{93}$ observes that, in E. 1.5, phantasiai are called tracheiai ("harsh") for being contrary to reason, making life

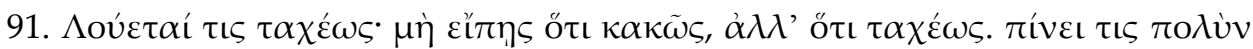

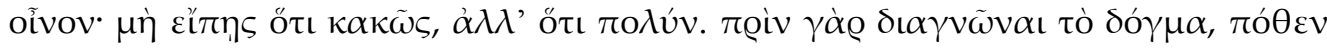

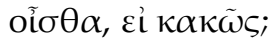

92. Cf. E 8.

93. Simplicius, Simplicius on Epictetus: Handbook 1-26. 
harsh. In Epictetus, this adjective only occurs in connection with the concept of phantasia in this line. In the Discourses, it always refers to difficult and painful situations. In D 1.2.9.1, for instance, Epictetus declares that "for to one human being it is consistent with reason to hold a chamber pot for another, and to look to this only, that if he does not hold it, he will receive stripes, and he will not receive his food: if he shall hold the pot, he will not suffer anything hard [trachy] or painful [aniaron]." In D 1.24.1, Epictetus observes that "It is difficulties [peristaseis] which show what people are. Therefore, when a difficulty falls upon you, remember that God, like a trainer of wrestlers, has matched you with a rough [trachei] young man." In D 2.1.19.2, talking about physical pain, Epictetus says: "The poor flesh is moved roughly [tracheos], then on the contrary smoothly." In D 3.10.7.4, where Epictetus explains how we must endure sickness, tracheo is employed as synonymous with peristasis ("difficult situation"). In D 3.24.32.3, the command of a general is described as "the harshest [trachyteron]." Finally, in D 4.5.33.2, the same adjective also occurs in the superlative, referring to Socrates' wife.

Therefore, we can say that tracheia phantasia means a harsh phantasia in the sense of a phantasia difficult to handle, a "difficult phantasia." Since it menaces the serenity of mind, all attention must be given to it. We have stated that Epictetus distinguishes four kinds of phantasiai (D 1.27): (1) it is something and so it seems; (2) it is not something and does not seem so; (3) it is something but does not seem so; (4) it is not something but it seems so. Types (1) and (2) are comprehensive phantasia, since what seems to be the case is in agreement with what is the case. Types (3) and (4), in turn, are not. We can say that a tracheia phantasia is either (3) or (4). In the case of a phantasia of something external to which value is added, it is either (3) something indifferent but does not seem so or it is (4) not something good or bad, but it seems so. What seems to be

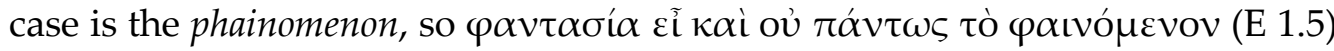
can be rendered as "you are a phantasia and absolutely not what you seem to be," which is Hadot's interpretation in La citadelle intérieure (1992). In the case of the tracheia phantasia of E 1, the phainomenon is a wrong dogma that, evaluating external things as good or bad, seems to be the case, a dogma that must be denied and replaced by a right one in order to keep the phantasia comprehensive and also a peaceful mind. 


\section{Bibliography}

Annas, Julia. Hellenistic Philosophy of Mind. Berkeley, University of California Press, 1991.

Benatouil, Thomas. Faire usage, la pratique du stoïcisme (Make use, the practice of stoicism). Paris: Vrin, 2006.

Boter, Gerard. Epictetus. The Encheiridion of Epictetus and its Three Christian Adaptations. Leiden: Brill, 1999.

Cicero. On the Nature of the Gods. Academics. Translated by Harris Rackham. Harvard: Loeb Classical Library, 1933.

Empiricus, Sextus. Against the Professors. Translated by R. G. Bury. Harvard: Loeb Classical Library, 1949.

Frede, Michael. "Stoics and skeptics on clear and distinct impressions." In Skeptic Tradition, edited by M. Burnyeat, 65-93. Berkeley: University of California Press, 1983.

Goldschmidt, Victor. Le Système stö̈cien et l'idée de temps (The Stoic system and the idea of time). Paris: Vrin, 1977.

Gourinat, Jean-Baptiste. Premières leçons sur Le Manuel d'Épictète (The first lessons of Epictetus' Manual. Paris PUF, 1998.

Hadot, Pierre. Manuel d'Épictète. Translated by Pierre Hadot. Paris: LGF, 2000.

Hadot, Pierre. La citadelle intérieure: Introduction aux Pensées de Marc Aurèle (The inner citadel: Introduction to the Meditations of Marcus Aurelius). Paris: Fayard, 1992.

Inwood, Brad, \& Gerson, Lloyd P. Hellenistic Philosophy: Introductory Readings. Indianapolis: Hackett Publishing Co., 1988.

Laertius, Diogenes. Lives of Eminent Philosophers, vol. I, II. Translated by Robert Drew Hicks. Harvard: Loeb Classical Library, 1925.

Lesses, Glenn. Content, Cause and Stoic Impressions. Phronesis XLIII/1 (1998): 2-24.

Long, Anthony, \& Sedley, David. Hellenistic Philosophers, vol. I. Cambridge: Cambridge University Press, 1987a.

Long, Anthony, \& Sedley, David. Hellenistic Philosophers, vol. II. Cambridge: Cambridge University Press, 1987b.

Long, Anthony. "Representation and the self in Stoicism." In Companions to Ancient Thought 2: Psychology edited by Stephen Everson, 102-120. Cambridge: Cambridge University Press, 1991.

Maltese, Enrico Valdo. Epictetus. Manuale. Milan: Garzanti, 1990.

Oldfather, William Abbott. Epictetus. The Discourses of Epictetus as reported by Arrian; Fragments; Encheiridion. Harvard: Loeb, 1928. 
Politianus, Angelus. Epicteti Stoici Enchiridion et Graeco interpretatum ab Angelo Poliziano (Stoic Epictetus' Enchiridion interpreted by Angelus Polician). Veneza: J. Anthonium et Fratres de Sabio, 1528.

Schweighäuser, Johann. Epicteteae Philosophiae Monumenta. 5 volumes. Leipzig: Teubner, 1799-1800.

Shields, Christopher. "The truth evaluability of stoic phantasiai: adversus mathematicos VII 242-46." Journal of the History of Philosophy 31 no. 3-July 1 (1993).

Simplicius. Simplicius on Epictetus: Handbook 1-26. Translated by Charles Brittain. Ithaca: Cornell University Press, 2002.

Sorabji, Richard. Perceptual Content in the Stoics. Phronesis XXXV/3 (1990): 307-314.

White, Nicholas. Epictetus. Epictetus, The Handbook, the Encheiridion. Cambridge: Hacket, 1983. 
